tion procedures or by methods which are known to be effective in rupturing the enveloping membranes of the particulate components of the liver cell.

2. Treatment of fresh liver microsomes, or acetone-dried whole rat liver, with crude pancreatic enzyme preparations in the presence of the nonionic detergent Lissapol-N effectively solubilizes arylsulphatase C, although some loss of enzyme activity occurs. Similar treatment with crystalline trypsin in the presence of Lissapol-N results in considerable destruction of arylsulphatase $\mathrm{C}$ and is ineffective in solubilizing the enzyme.

3. The final soluble preparation of arylsulphatase $C$ is unstable at room temperature and still contains traces of rat-liver arylsulphatases $\mathrm{A}$ and $\mathrm{B}$.

This work was aided by apparatus grants from the Royal Society, the Medical Research Council and Imperial Chemical Industries Ltd. One of us (F.A.R.) is grateful to the Medical Research Council for a studentship.

\section{REFERENCES}

Beaufay, H. \& de Duve, C. (1954). Bull. Soc. Chim. biol., Paris, 36, 1551.

Bücher, T. (1953). Advanc. Enzymol. 14, 1.
Dodgson, K. S., Rose, F. A., Spencer, B. \& Thomas, J. (1957). Biochem. J. 66, 363.

Dodgson, K. S. \& Spencer, B. (1953). Biochem. J. 53, 444.

Dodgson, K. S. \& Spencer, B. (1957). Biochem. J. 65, 668.

Dodgson, K. S., Spencer, B. \& Thomas, J. (1954). Biochem.J. 56, 177.

Dodgson, K. S., Spencer, B. \& Thomas, J. (1955). Biochem.J. 59, 29.

Dodgson, K. S., Spencer, B. \&Wynn,C. H. (1956). Biochem.J. $62,500$.

Dounce, A. L. (1950). In The Enzymes, vol. 1, part 1. Ed. by Sumner, J. B. \& Myrbäck, K. New York: Academic Press Inc.

Gianetto, R. \& Viala, R. (1955). Science, 121, 158.

Hers, G., Berthet, J., Berthet, L. \& de Duve, C. (1951). Bull. Soc. Chim. biol., Paris, 33, 21.

Mickle, H. (1948). J. R. micr. Soc. 68, 10.

Morton, R. K. (1955). In Methods in Enzymology, vol. 1, p. 25. New York: Academic Press Inc.

Potter, V. R. \& Elvehjem, C. G. (1936). J. biol. Chem. 114, 495.

Schneider, W. C. (1948). J. biol. Chem. 176, 259.

Slautterback, D. B. (1952). Exp. Cell Res. 5, 173.

Viala, R. \& Gianetto, R. (1955). Canad. J. Biochem. Physiol. 33, 839.

\title{
Studies on Sulphatases
}

\section{THE ACTION OF SURFACE-ACTIVE AGENTS ON THE ARYLSULPHATASE C OF RAT LIVER}

\author{
By K. S. DODGSON, F. A. ROSE, B. SPENCER* AND J. THOMAS $\uparrow$ \\ Department of Biochemistry, University of Wales, Newport Road, Cardiff
}

(Received 27 November 1956)

Arylsulphatase $\mathrm{C}$ of rat-liver microsomes cannot readily be obtained in solution. Attempts to solubilize this enzyme have been reported in the preceding paper (Dodgson, Rose \& Spencer, 1957), a soluble preparation finally being obtained by incubating microsomes with pancreatic preparations in the presence of the synthetic non-ionic surface-active agent, Lissapol-N.

During these investigations it was noted that a number of surface-active agents were apparently capable of solubilizing arylsulphatase $\mathrm{C}$ and, in view of the several interesting phenomena observed, this work has been considered separately. A preliminary account of the work has already appeared (Spencer, Dodgson, Rose \& Thomas, 1955).

* Present address: Wernse Cancer Laboratories, Washington University, St Louis, Mo.

$\dagger$ Present address: Lister Institute of Preventive Medicine, Chelsea Bridge Road, London, S.W. 1.

\section{EXPERIMENTAL}

Acetone-dried rat liver. Fresh rat liver (50 g.) was macerated for $3 \mathrm{~min}$. in a Townson and Mercer macerator with $300 \mathrm{ml}$. of acetone at $0^{\circ}$. The macerated material was filtered at the pump and the filter cake immediately re-macerated with a further $300 \mathrm{ml}$. of acetone at $0^{\circ}$. After filtering at the pump the filter cake was washed with three $300 \mathrm{ml}$. portions of cold acetone, sucked dry at the pump, and broken up and dried in vacuo. The dried powder was sieved (40-mesh) in order to remove connective tissue.

Assay of arylsulphatase $C$. The methods of assay were those employed previously (Dodgson et al. 1957), potassium $p$-nitrophenylsulphate (NPS) and $p$-acetylphenylsulphate (APS) being used. The activities of fresh whole-liver suspensions were measured with APS, and those of microsomes and acetone-dried powders were assayed with NPS. The surface-active agents did not hydrolyse these substrates under the conditions of assay and did not interfere with the recovery of the phenols which were liberated as a result of enzyme action. 
Surface-active agents. Lissapol-N, an alkylarylpolyethoxy alcohol (Imperial Chemical Industries Ltd.), Sterox S.E., a polyoxyethylene thio ether (Monsanto Chemicals Ltd.) and Triton WR-1339, the concentrated form of Triton A-20 (Rohm and Hass Ltd.) are non-ionic surface-active agents. Teepol 530, a mixture of the sodium salts of sec.-alkyl sulphates (Shell Chemicals Ltd.), sodium dodecyl sulphate (L. Light and Co.) and cholic acid are anionic detergents. Cetylpyridinium bromide (L. Light and Co.) and cetyltrimethylammonium bromide (British Drug Houses Ltd.) are cationic agents.

Measurement of the solubilizing effect of surface-active agents. Water suspensions of fresh or acetone-dried whole liver, or of microsomes isolated by the method of Schneider (1948), were made with a glass homogenizer. An aqueous solution of the detergent, of twice the concentration required, was adjusted to $\mathrm{pH} 7.0$ with $\mathrm{NaOH}$ or acetic acid and added to an equal volume of the tissue suspension at $4^{\circ}$. A portion of the mixture was withdrawn for arylsulphatase $\mathrm{C}$ assay, and the remainder was centrifuged at $25000 \mathrm{~g}$ at $0^{\circ}$ for $30 \mathrm{~min}$. The amount of arylsulphatase $\mathrm{C}$ in solution was then assessed by comparing the enzyme activity of the uncentrifuged mixture with that of the centrifuged supernatant. The arylsulphatase activity of the untreated tissue suspensions was also measured in order to assess the degree of inhibition or activation resulting from the detergent treatment.

\section{RESULTS}

\section{Effect of non-ionic surface-active agents}

The effect of Lissapol-N on the activity and solubility of the arylsulphatase $\mathrm{C}$ of acetone-dried rat liver is shown in Fig. 1. For reasons which will subsequently be apparent, in this and all other figures the effect of the detergent on the activity and solubility of the enzyme has been plotted against the logarithm of the detergent concentration. At low concentrations of detergent little enzyme was released into solution, but as the concentration of detergent was increased there was a sharp rise in the solubility of the arylsulphatase to a maximum of about $85 \%$ of the total enzyme present. The degree of solubilization was not dependent on the period of contact of the enzyme with the detergent, and no further increase in solubility occurred after incubation of acetone-dried liver for $3 \mathrm{hr}$. at $37^{\circ}$, with a concentration of detergent which immediately solubilized $30 \%$ of the total enzyme present. Prolonged centrifuging ( $3 \mathrm{hr}$. at $25000 \mathrm{~g}$ and $0^{\circ}$ ) of the soluble material prepared by Lissapol-N treatment failed to sediment any arylsulphatase $C$. The concentration of Lissapol-N necessary to achieve maximum solubility of the arylsulphatase varied with the concentration of the tissue suspension. The solubilization of the arylsulphatase was accompanied by an increase in enzyme activity, the shape of the two curves (Fig. 1) showing a high degree of correspondence. Non-ionic surface-active agents are incapable of electrostatic interaction with proteins (Glassman, 1950), and it seems probable that the activation of arylsulphatase $\mathrm{C}$ by Lissapol-N is simply due to increased dispersion of the enzyme.

When present in dilute solution detergents are considered to exist as simple ions or molecules, but in higher concentrations the ions or molecules associate to form colloidal aggregates which are known as micelles (Hartley, 1936; McBain, 1944). Micelle formation occurs rather abruptly when a certain critical concentration (the critical micelle concentration) of detergent is exceeded and is associated with marked changes in the physical properties of the detergent solution (McBain, 1944). Within recent years it has been shown, in a number of cases, that abrupt changes in the behaviour of detergent-treated biological systems can also often be correlated with detergent-micelle formation. Thus Hughes (1950), during a study of the effects of detergents on the rate of decarboxylation of glutamate by intact cells and extracts of Clostridium welchii, showed that the marked increase in enzyme activity which was observed above certain detergent concentrations occurred simultaneously with the formation of detergent micelles. More recently, Cowgill (1955) has related the activation or inhibition of rabbit-muscle phosphorylase by various detergents to detergent micelle formation. In such cases, when the extent of the effect of detergent on the particular property under investigation is plotted against the logarithm of the detergent concentration, sigmoid curves similar to those shown in Fig. 1 are obtained. Other examples of similar

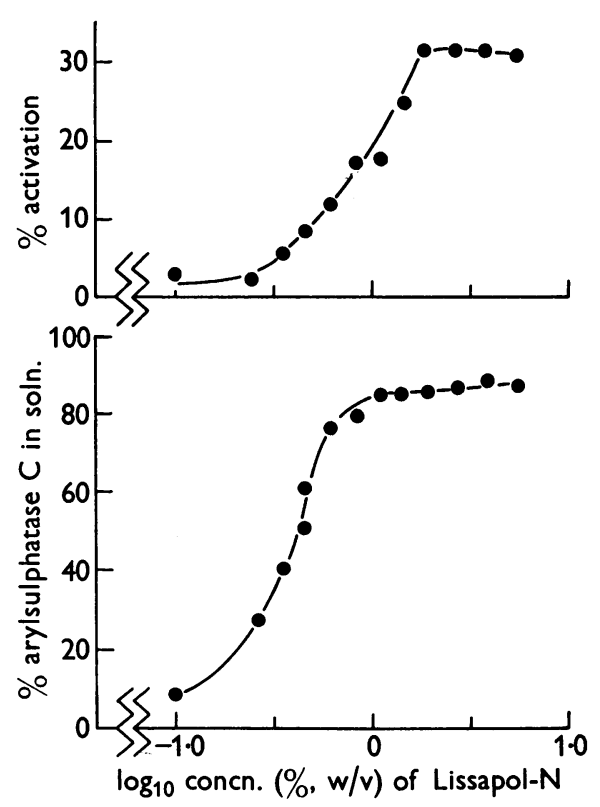

Fig. 1. Effect of Lissapol-N on the solubility and activity of the arylsulphatase $\mathrm{C}$ present in an aqueous suspension (final concentration $\mathbf{0 . 3} \%$ ) of acetone-dried rat liver. 
sigmoid curves are to be found in the works of Scott \& Tartar (1943) and Ralston (1946), in which the effects of detergent concentration on the surface tension and electrical conductivity of detergent solutions have been studied.

Lissapol-N similarly solubilized the arylsulphatase $\mathrm{C}$ of fresh whole-liver suspensions and suspensions of freshly prepared microsomes, the plot of solubility or activation of the enzyme against the logarithm of the concentration of the detergent showing the typical sigmoid shape in each case. In contrast to the $85 \%$ solubilization achieved with the acetone-dried liver (Fig. 1), the arylsulphatase C of fresh tissues was completely solubilized by Lissapol-N treatment. Repeated treatment of liver preparations with acetone resulted in a progressive decrease in the amount of arylsulphatase $\mathrm{C}$ which could subsequently be solubilized.

Sterox S.E. solubilized the arylsulphatase C of fresh and acetone-dried rat liver, the solubility curves again being sigmoid in character and similar to those obtained with Lissapol-N. The arylsulphatase $\mathrm{C}$ present in $\mathbf{l} \mathrm{g}$. of fresh liver was completely solubilized by $0.02 \mathrm{~g}$. of Sterox S.E. Both Lissapol-N and Sterox S.E. are haemolytic surfaceactive agents. Glassman (1950) has shown that Triton A-20, a non-ionic detergent, is non-haemolytic, and its effect on the solubility of rat-liver arylsulphatase $\mathrm{C}$ was therefore studied. Triton WR-1339 (the concentrated form of Triton A-20), even in concentrations as high as $5 \mathrm{~g} . / \mathrm{g}$. of fresh liver $/ 100 \mathrm{ml}$. of water, failed to solubilize the enzyme. At the highest concentration used, an apparent solubilization of $12 \%$ of the enzyme activity was achieved, but this figure was reduced to $2 \%$ by centrifuging for $3 \mathrm{hr}$. at $25000 \mathrm{~g}$; this suggests that the apparent $12 \%$ solubilization originally observed was due to failure to sediment the insoluble enzyme from the concentrated detergent-tissue suspension mixture of such high specific gravity. Incubation of fresh liver with Triton WR-1339 for $3 \mathrm{hr}$. at $37^{\circ}$ did not solubilize arylsulphatase $\mathrm{C}$, and addition of an aqueous solution of Triton WR-1339 (5\%, w/v) to a $1 \%$ (wet wt./v) suspension of fresh liver containing sufficient Lissapol-N to solubilize $50 \%$ of the enzyme did not increase the degree of solubilization. The reason for the failure of Triton WR-1339 to solubilize arylsulphatase $\mathrm{C}$ is not clear; possibly detergent micelles are absent even at the high concentration of detergent used.

\section{Effect of cationic surface-active agents}

Fig. 2 shows that the solubilization of the arylsulphatase $\mathrm{C}$ of acetone-dried rat liver by cetylpyridinium bromide also occurred abruptly as the concentration of detergent was increased. Again a sigmoid solubility curve was obtained. With cetyl- pyridinium bromide it was possible to determine the critical micelle concentration in the tissue suspension-detergent mixture by making use of an observation of Hartley (1923), who noted the ability of surface-active agents, when present in concentrations greater than the critical micelle concentration, to change the colour of certain indicator solutions without affecting the $\mathrm{pH}$. The method of Hughes (1950) was modified slightly. Tissue suspensions containing varying amounts of detergent were prepared in $0.1 \mathrm{M}$-acetate buffer at $\mathrm{pH} 4 \cdot 0$, and $4 \mathrm{ml}$. portions of the various suspensions were then treated with two drops of $0.4 \%$ aqueous methyl orange. A resultant bright canary-yellow colour indicated the presence of micelles. Fig. 2 shows that the critical micelle concentration found by this method coincided with the sharp rise in solubility of arylsulphatase $\mathrm{C}$.

The maximum solubilization of the arylsulphatase C of acetone-dried liver, which was achieved by treatment with cetylpyridinium bromide, was approximately $85 \%$ (Fig. 2), but in the fresh liver suspensions complete solubility could be obtained. Solubilization was accompanied in both cases by enzyme activation (30\%) (cf. Fig. 2) and this can
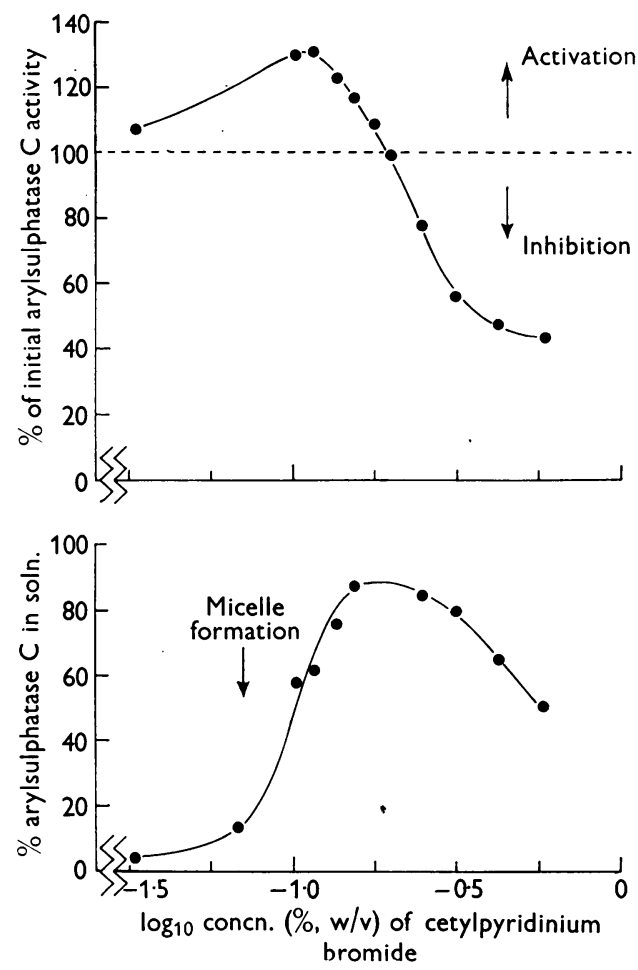

Fig. 2. Effect of cetylpyridinium bromide on the solubility and activity of the arylsulphatase $C$ present in an aqueous suspension (final concentration, $\mathbf{0 . 3} \%$ ) of acetone-dried rat liver. 
probably be attributed to dispersion of the enzyme. Cetyltrimethylammonium bromide also solubilized the arylsulphatase $\mathrm{C}$ of acetone-dried liver to the extent of about $85 \%$.

When present in concentrations much greater than the critical micelle concentration, cetylpyridinium bromide inhibited the arylsulphatase and, of the arylsulphatase activity remaining, less was now present in soluble form. The enzyme could be protected to varying degrees against the inhibition by the addition of different concentrations of inert protein (boiled rat-liver suspension) before detergent treatment. If inert protein was added after detergent treatment then less protection was afforded, the degree of protection decreasing with increasing delay in the addition of the inert protein. Inert protein added $1.5 \mathrm{hr}$. after the commencement of detergent treatment afforded no protection against the inhibition. It seems clear that the inhibiting effect of high concentrations of cetylpyridinium bromide can be attributed to denaturation of enzyme protein. Cationic detergents when present in high concentrations are known to denature proteins (Putnam, 1948).

\section{Effect of anionic surface-active agents}

Teepol 530 strongly inhibited arylsulphatase C but at the same time solubilized the enzyme (Fig. 3). Maximum solubilization of the arylsulphatase $\mathbf{C}$ of acetone-dried liver was achieved with a Teepol 530 concentration which caused
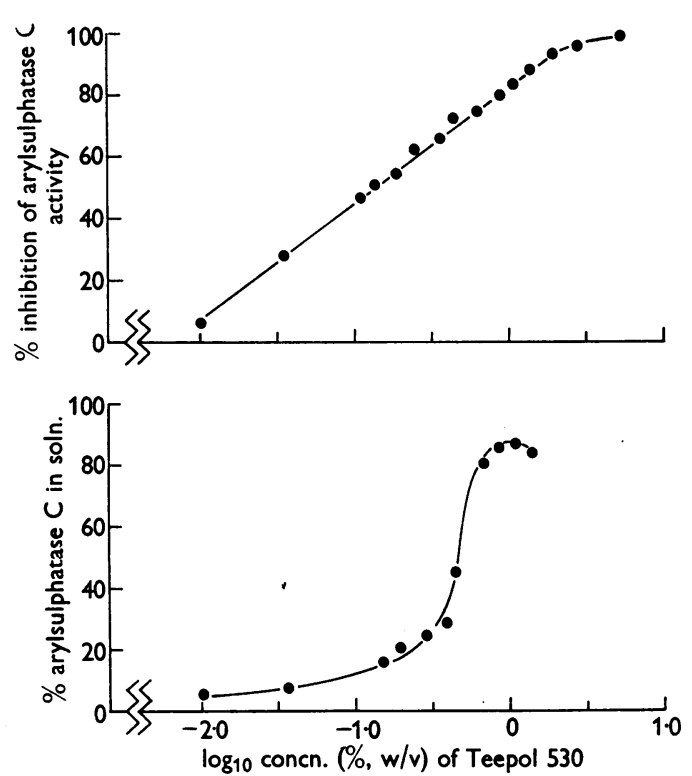

Fig. 3. Effect of Teepol 530 on the solubility and activity of the arylsulphatase $\mathrm{C}$ present in an aqueous suspension (final concentration, $0.3 \%$ ) of acetone-dried rat liver.
$80 \%$ inhibition of the activity obtained in the absence of detergent. The solubilization curve showed the sigmoid shape associated with micelle formation, but inhibition commenced with very low concentrations of Teepol 530 and was obviously due to the ionic form of the detergent.

Sodium dodecyl sulphate showed the same solubilization and activation pattern as Teepol 530 . Thus $87 \%$ solubilization of the remaining arylsulphatase $C$ was achieved with the loss of $83 \%$ of the original activity. Inhibition by both Teepol 530 and sodium dodecyl sulphate could be reduced to some extent (10-20\%) by adding inactive protein (boiled-enzyme suspension) to the detergentenzyme mixture. Delay in the addition of the boiled suspension up to a period of $90 \mathrm{~min}$. after the preparation of the detergent-enzyme mixture did not decrease the protective power of the boiled suspension. This suggested that inhibition by both detergents was reversible.

Solubilization of arylsulphatase C which was associated with micelle formation and inhibition of the enzyme by the detergent ion was also achieved with sodium cholate (Fig. 4). The inhibition by cholate was different from that obtained with Teepol 530 and sodium dodecyl sulphate in that it did not proceed to completion but reached a limiting value of about $80 \%$. This value was reached at a concentration of cholate with which maximum

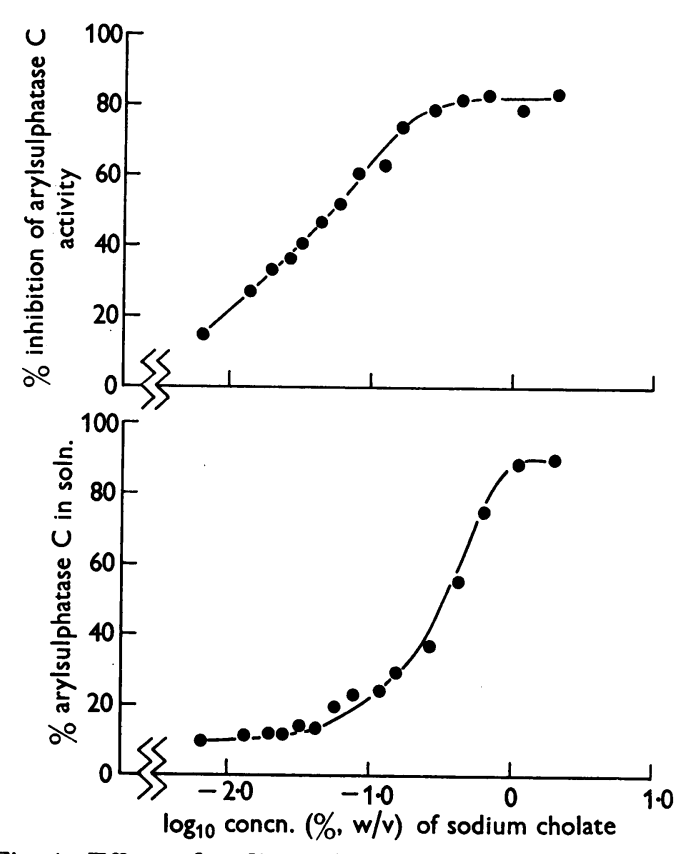

Fig. 4. Effect of sodium cholate on the solubility and activity of the arylsulphatase $\mathrm{C}$ present in an aqueous suspension (final concentration, $0 \cdot 3 \%$ ) of acetone-dried rat liver. 
solubilization of the arylsulphatase had been achieved and, at this point, free micelles unattached to protein were presumably present in the tissuedetergent mixture. Under conditions where micelle formation is complete, further addition of surfaceactive agent does not increase the concentration of detergent ion, and thus inhibition by cholate does not increase. With Teepol 530 (Fig. 3) and sodium dodecyl sulphate, complete inhibition of the arylsulphatase was achieved in spite of the fact that solubilization of the arylsulphatase had reached a maximum (and micelle formation was therefore presumably complete) at concentrations of these detergents which inhibited to the extent of only $85 \%$. It must be assumed that the further inhibition which occurs with these two detergents after micelle formation is complete is due to denaturation of the enzyme by the high concentrations of surfaceactive agent, or alternatively to inhibition by the detergent micelles.

The inhibition of arylsulphatase $\mathbf{C}$ by the ions of the anionic detergents was shown to be competitive by the method of Hunter \& Downs (1945). In this method, the fractional activity given in the presence of inhibitor (of molar concentration [I]) is denoted by $\alpha$, and the plot of $[I] \times \alpha /(1-\alpha)$ against $[S]$, the substrate concentration, is a straight line parallel to the abscissa when inhibition is non-competitive, and an ascending straight line which cuts the ordinate axis at a value equal to $K_{i}$ when inhibition is competitive. Both Teepol and sodium dodecyl sulphate ions were competitive inhibitors, but the apparent values of the enzyme-inhibitor complex dissociation constant $K_{i}$ derived from the graphs had no significance owing to the binding of unknown amounts of detergent ions by the relatively large amounts of inactive protein present in the tissue preparations.

\section{State of arylsulphatase $C$ after detergent treatment}

Strictly the solubilization of an enzyme by a detergent can only be considered to have been achieved if the enzyme remains in solution after complete removal of the detergent.

After solubilizing the arylsulphatase C of acetonedried rat liver with Lissapol-N and removing insoluble material by centrifuging, the clear supernatant was fractionally precipitated with $\left(\mathrm{NH}_{4}\right)_{2} \mathrm{SO}_{4}$. The major portion (70\%) of the activity was precipitated at $20 \%$ saturation and this fraction was suspended in water and dialysed overnight against running tap water. The enzyme activity of this preparation was completely in solution and could be reprecipitated with $\left(\mathrm{NH}_{4}\right)_{2} \mathrm{SO}_{4}$ and subsequently redissolved in water. However, the final enzyme solution showed excessive frothing on stirring, thus indicating the presence of detergent. In order to remove the Lissapol-N completely the arylsul- phatase was precipitated by treatment of the solution with acetone at $0^{\circ}$ until the acetone concentration was $80 \%(v / v)$. The arylsulphatase activity of the acetone-dried powder obtained was completely insoluble. Treatment with acetone of both non-ionic and cationic detergent-solubilized preparations of the enzyme, which had not been previously precipitated by $\left(\mathrm{NH}_{4}\right)_{2} \mathrm{SO}_{4}$, gave similar results. Inadequate washing with acetone during the preparation of such acetone-dried powders sometimes resulted in a material containing a certain amount of soluble enzyme which, however, became insoluble after further washing with acetone. The arylsulphatase activity of detergent-free powder could not be obtained in solution by treatment with $0.5 \mathrm{M}$ acetate buffers (pH 4-7), 0.2 M-phosphate buffers (pH 7.5-9.5), or after treatment with $n$-butanol (Morton, 1955). It was evident that the reappearance of insoluble enzyme material after the acetone treatment of the detergent-solubilized arylsulphatase could be attributed to the removal of detergent rather than to any denaturating effect of the acetone, since the enzyme could again be solubilized by non-ionic or cationic surface-active agents. The solubilization curve again showed the sigmoid character associated with detergentmicelle formation.

\section{DISCUSSION}

At least two different mechanisms have been recognized by which enzymes and other proteins can be brought into solution by the action of detergents. Thus some enzymes which are contained within a membrane, such as that of the cell or of the constituent mitochondria or microsomes, are dissolved in the medium employed when the restricting membrane is disrupted by the action of a detergent. The sulphatase activity of rat-liver mitochondria towards dipotassium 2-hydroxy-5-nitrophenyl sulphate (action of arylsulphatases $A$ and $B$, cf. Dodgson \& Spencer, 1957), and the acid phosphatase of such particles, can be released into solution after the rupture of the mitochondrial membrane by mechanical means, alternate freezing and thawing or acetone-drying (Viala \& Gianetto, 1955; Dodgson, Spencer \& Thomas, 1955). Triton X-100, a non-ionic surface-active agent, also releases these enzymes, presumably by breaking the membrane. It is clear that reaction between enzyme and detergent is not an integral part of solubilization of enzymes by this mechanism and the enzyme remains in solution after the removal of detergent.

A second mechanism depends on the ability of certain ionic surface-active agents to rupture protein-protein and protein-lipid linkages (Putnam, 1948). In those cases where an enzyme or other protein exists as an insoluble conjugated complex 
the dissociating action of detergents often results in the release of the enzyme in a soluble form. In this type of solubilization appreciable enzyme inhibition or activation may occur as a result of the interaction of charged detergent and enzyme complex. Once the complex has been dissociated the presence of surface-active agent is no longer necessary in order to retain the enzyme in solution. Thus the acetylcholinesterase of haemolysed human red cells was solubilized by the use of Tween 20 (polyoxyethylene sorbitan monolaurate) and remained in solution after the removal of the detergent with acetone. The acetylcholinesterase normally exists as an insoluble lipid-protein complex and the release of the enzyme was assumed to have involved dissociation of the complex by the detergent (Zittle, Dellamonica \& Custer, 1954).

Neither of the two mechanisms mentioned above appears to be involved in the solubilization of the arylsulphatase $\mathrm{C}$ of rat-liver microsomes, since the continued presence of surface-active agent is necessary in order to retain the enzyme in solution. Moreover, the dissociation of a lipid-protein or similar complex is unlikely to occur with a nonionic detergent such as Lissapol-N (cf. Morton, 1955). The salient points of the solubilization of arylsulphatase $\mathbf{C}$ are that solubilization is closely associated with micelle formation by the detergent and that the enzyme is held in solution only if detergent is present. These events strongly suggest that the formation of a soluble micelle-enzyme complex occurs. Klevens (1950) has discussed the problem of solubilization involving detergent micelles and has correlated the results of a large number of investigators, the majority of whom, however, were studying the effect of detergents on non-biological materials. He concludes that such solubilization could occur in three possible ways: by adsorption of the insoluble material by the micelle, usually on or near the detergent-water interface; by incorporation of the insoluble material into the hydrocarbon centre of the micelle, or by penetration into the palisade layer of the micelle. Adsorption of insoluble material by the micelle can probably be ruled out in the present case since it appears to be applicable to the solubilization of compounds of low molecular weight only. It is not possible to say which of the two remaining mechanisms might apply to the present case and such a decision can only be made after X-ray measurement of the detergent-enzyme complex.

Further examples of solubilization procedures which involve detergent micelles would appear to be the solubilization of alkaline phosphatase by bile salts (Mathies, 1951) and glucose 6-phosphatase by sodium deoxycholate (Beaufay \& de Duve, 1954). Although in these two cases micelle formation was not measured it seems justifiable to include them in the present category since a soluble preparation, free from detergent, could not be obtained.

\section{SUMMARY}

1. The arylsulphatase $\mathrm{C}$ of rat-liver microsomes was solubilized by cationic and non-ionic surfaceactive agents, solubilization being accompanied by activation of the enzyme. Both the solubilizing and activating effects were associated with micelle formation by the detergents.

2. Anionic surface-active agents in the ionic form acted as strong competitive inhibitors of the enzyme but solubiliźation of the remaining activity was achieved and was associated with micelle formation by the detergent.

3. In all cases the solubilized arylsulphatase $\mathbf{C}$ became insoluble on removal of the detergent.

This work was aided by apparatus grants from the Royal Society, the Medical Research Council and Imperial Chemical Industries Ltd. We are grateful to Monsanto Chemicals Ltd., Rohm and Haas Ltd. and I.C.I. Ltd. for generous gifts of detergents. One of us (F.A.R.) is grateful to the Medical Research Council for a studentship.

\section{REFERENCES}

Beaufay, H. \& de Duve, C. (1954). Bull. Soc. Chim. biol., Paris, 36, 1551.

Cowgill, R. W. (1955). Biochem. biophys. Acta, 14, 583.

Dodgson, K. S., Rose, F. A. \& Spencer, B. (1957). Biochem. J. 66, 357.

Dodgson, K. S. \& Spencer, B. (1957). Methods in Biochemical Analysis, vol. 4. New York: Interscience Publishers Inc. (in the Press).

Dodgson, K.S., Spencer, B. \& Thomas, J.(1955). Biochem.J. $59,29$.

Glassman, H. N. (1950). Science, 111, 688.

Hartley, G. S. (1923). Trans. Faraday Soc. 30, 444.

Hartley, G. S. (1936). Aqueous Solutions of Paraffin-chain Salts. Paris: Harman et Cie.

Hughes, D. E. (1950). Biochem. J. 46, 231.

Hunter, A. \& Downs, C. E. (1945). J. biol. Chem. 157, 427.

Klevens, H. B. (1950). Chem. Rev. 47, 1.

McBain, J. W. (1944). In Colloid Chemistry, vol. 5, p. 102. By Alexander, J. New York: Reinhold.

Mathies, J. C. (1951). Biochim. biophys. Acta, 7, 387.

Morton, R. K. (1955). Methods in Enzymology, vol. 1, p. 25. New York: Academic Press Inc.

Putnam, F. W. (1948). Advanc. Protein Chem. 4, 79.

Ralston, A. W. (1946). Ann. N.Y. Acad. Sci. 46, 351.

Schneider, W. C. (1948). J. biol. Chem. 176, 259.

Scott, F. B. \& Tartar, H. V. (1943). J. Amer. chem. Soc. 65, 692.

Spencer, B., Dodgson, K. S., Rose, F. A. \& Thomas, J. (1955). Résumés des Communications, 3rd Int. Congr. Biochem., Brussels, p. 28 (4-20).

Viala, R. \& Gianetto, R. (1955). Canad. J. Biochem. Physiol. 33, 839.

Zittle, C. A., Dellamonica, E. S. \& Custer, J. H. (1954). Arch. Biochem. Biophys. 48, 43. 